\title{
Pengaruh pH dan Jenis Pelarut terhadap Ekstraksi Batch Asam 6-Aminopenisilinat
}

\author{
Lienda Aliwarga *, Reynard, Iga Putri Yasmani, Mia Puspasari
}

Program Studi Teknik Kimia, Fakultas Teknologi Industri, Institut Teknologi Bandung, Jalan Ganesha 10 Bandung 40132

*e-mail: lienda@che.itb.ac.id

\begin{abstract}
Abstrak. Asam 6-aminopenisilinat (6-APA) merupakan bahan dasar pembuatan penisilin semi-sintetis. Dalam skala komersial, 6-APA dapat diproduksi dengan cara enzimatis atau kimiawi. Pada umumnya, produksi 6-APA dilakukan secara enzimatis, yaitu dengan mengkonversi penisilin $G$ menjadi 6-APA dengan bantuan penisilin asilase. Karena konversi merupakan reaksi kesetimbangan, maka produk yang didapat adalah campuran penisilin $G$, 6-APA, dan asam fenil asetat (PAA) sehingga untuk memperoleh 6-APA murni dilakukan proses ekstraksi, pemekatan, dan kristalisasi. Proses ini dipengaruhi oleh beberapa variabel operasi, yaitu temperatur, $p H$, dan jenis pelarut. Dalam penelitian ini akan dipelajari pengaruh $\mathrm{pH}$ dan jenis pelarut terhadap proses pemisahan 6-APA. Temperatur operasi adalah kondisi ruang dan perbandingan volume pelarut dengan volume larutan yang akan diekstraksi adalah 1:1. Variasi pH ekstraksi dilakukan antara rentang 2,0-5,0, sedangkan jenis pelarut yang digunakan adalah n-butil asetat, iso butil asetat, metil isobutil keton, dan iso amil asetat. Rentang pH terbaik untuk pemisahan 6-APA adalah 2,0-3,0 dengan pelarut metil isobutil keton. Pada kondisi ini, perolehan penisilin G adalah 98\%, 6-APA 5\%, dan PAA 99\%. Sebagian besar 6-APA pada fase aquatik dapat diproses untuk pemurnian selanjutnya.
\end{abstract}

Kata kunci: Penisilin G, 6-APA, PAA, ekstraksi, pelarut, $p H$.

Abstract. Influence of pH and Solvent Types on 6-Aminopenicillinic Acid Batch Extraction. 6-aminopenicillinic acid (6-APA) is the raw material for producing semi-synthetic penicillin. In commercial scale, penicillin $G$ is converted into 6-APA enzymatically by penicillin acylase. Due to the nature of equilibrium reaction, the products are in mixture solution of penicillin G, 6-APA, and phenyl acetic acid (PAA). In order to purify the targeted 6-APA, steps of extraction, concentration, and crystallisation are thereby compulsory. Extraction process is influenced by operation variables, among other things, temperature, $\mathrm{pH}$, and solvent types. In this experiment, we observed the aspects of $\mathrm{pH}$ and solvent type, while temperature was set in room condition. Volume ratio of solvent to extracted solution was $1: 1$ and $\mathrm{pH}$ was varied between 2.0 and 5.0. There were four solvents tested: $n$-butyl acetate, isobutyl acetate, methyl isobutyl ketone, and isoamyl acetate. The results suggested that optimum process was attained from pH 2.0 to 3.0, using methyl isobutyl ketone as solvent. In this regard, the yield of penicillin G (98\%), 6-APA 95\%) and PAA (99\%); hence, most of the 6-APA was concentrated within the aquatic phase, representing the ease of further process.

Keywords: Penicillin G, 6-APA, PAA, extraction, solvent, $p H$.

\section{Graphical Abstract}

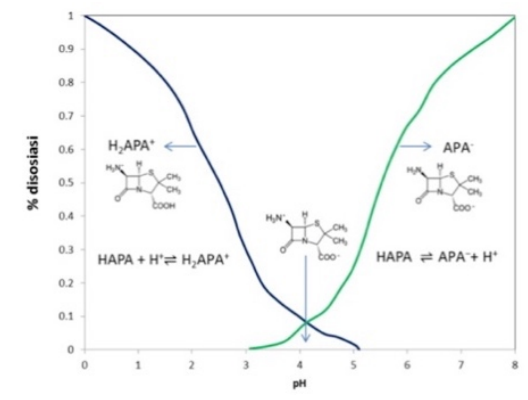

\section{Pendahuluan}

Penggunaan penisilin semi-sintetis sebagai penggati penisilin alami saat ini semakin meluas karena sifat mikroorganisme patogen yang mulai resisten terhadap penisilin alami. Asam 6-aminopenisilinat (6-APA) merupakan bahan dasar pembuatan penisilin semisintetis, dan melalui pemrosesan lebih lanjut, ribuan jenis penisilin semi-sintetis baru, yang tahan terhadap beta laktamsase dan memiliki spektrum luas dapat dihasilkan. Keunggulan utama dari penisilin semi-sintetis ini adalah sifatnya yang lebih stabil dalam suasana asam dan ketahanan terhadap enzim pensilinase. Secara komersial, 6-APA dihasilkan melalui reaksi kesetimbangan enzimatis menggunakan penisilin amilase (Vandamme dan Voets, 1974). Hasil reaksi merupakan campuran dari komponen 6-APA, penisilin G, dan asam 
fenil asetat (PAA) (Zhukovskaya, 1974; Bruggink dkk., 1998; Singh dan Goyal, 2014). Pemisahan terhadap 6APA umumnya dilakukan dengan beberapa tahapan, yaitu filtrasi untuk memisahkan miselia dari penisilin, ekstraksi dan carbon treatment untuk memisahkan kontaminan, kristalisasi untuk pemurnian lebih lanjut yang disertai stabilisasi, dan pengeringan. Proses pemurnian dengan tahapan tersebut menghasilkan tingkat kemurnian sebesar 90\%. Ekstraksi, yang merupakan tahapan awal pemisahan selanjutnya, seperti tahap pemekatan dan kristalisasi (Huper, 1972; Harvey dkk., 2018).

Variabel yang berpengaruh terhadap perolehan 6APA dalam proses ekstraksi, di antaranya adalah $\mathrm{pH}$, jenis pelarut, dan temperatur ekstraksi (Schugerl dan Degener, 1992). Ivaskhiv, 1964 telah menunjukkan bahwa $\mathrm{pH}$ optimum esktraksi ada pada rentang 2,0-5,0 (Ivaskhiv, 1964). Selain itu, diketahui pula bahwa ekstraksi lebih baik dilakukan pada temperatur rendah 0$3^{\circ} \mathrm{C}$ (Elder, 1970). Terkait dengan jenis pelarut, senyawa ester memberikan performansi terbaik (Schugerl dan Degener, 1992) dan perbandingan volume pelarut terhadap volume larutan tidak memengaruhi hasil ekstraksi (Ivaskhiv, 1964). Sebagian besar penisilin G dan PAA akan terekstrak ke fase organik, sedangkan 6APA akan tetap tinggal di fase aquatik. Penisilin dapat terekstrak dari fase aquatik ke fase organik dalam bentuk asam bebas dan dari pelarut organik ke larutan basa dalam bentuk garamnya (Misek, 1978). Pengondisian ekstraksi kaldu fermentasi pada $\mathrm{pH}$ 2,0-3,0, temperatur $2{ }^{\circ} \mathrm{C}$, dan pelarut amil asetat memberikan perolehan penisilin G sebesar 96\% (Harvey dkk., 2018).

Penelitian terdahulu oleh Batchelor dkk., 1961 (Batchelor dkk., 1961) dilakukan terhadap campuran kompleks kaldu fermentasi. Ekstraksi cair-cair yang diupayakan untuk memperoleh gambaran proses pemisahan tiga komponen utama fermentasi terkait, yaitu penisilin G, 6-APA, dan PAA belum pernah dipublikasikan sebelumnya dan akan dilakukan dalam percobaan ini. Parameter yang digunakan untuk menentukan keberhasilan dari proses pemisahan ini adalah perolehan 6-APA, penisilin G, dan PAA setelah proses ekstraksi. Dengan kata lain, perolehan di fase organik yang setinggi-tingginya untuk penisilin $G$ dan PAA, serta perolehan 6-APA yang sekecil-kecilnya perlu dicapai dalam proses ini.

\section{Metodologi}

Langkah-langkah percobaan yang dilakukan adalah preparasi larutan model, ekstraksi pelarut, analisis konsentrasi dan yield 6-APA, PAA, dan Penisilin G menggunakan HPLC.

\subsection{Alat dan bahan}

Penisilin G (kemurnian 96,0\% dalam bentuk garam natrium), asam 6-aminopenisilinat (6-APA) dengan kemurnian $96 \%$, dan asam fenil asetat (PAA) dengan kemurnian $96 \%$ yang digunakan dalam studi ini diperoleh dari Sigma Chemical \& Co. Pelarut n-butil asetat (kemurnian $\geq 99,5 \%$ ), iso butil asetat (kemurnian $\geq 98,0 \%$ ), metil isobutil keton (kemurnian $\geq 99,0 \%$ ), dan iso amil asetat (kemurnian $\geq 99,0 \%$ ) yang digunakan dalam studi ini diperoleh dari Merck Millipore. Untuk memperoleh hasil eksperimen yang konsisten, maka seluruh bahan yang digunakan adalah kualitas untuk analisis. Air terdistilasi digunakan secara menyeluruh untuk eksperimen ini.

\subsection{Preparasi larutan model}

Sebanyak 0,0891 gram penisilin G, 0,0864 gram 6APA, dan 0,0544 gram PAA dilarutkan dengan buffer sitrat-fosfat pada $\mathrm{pH}$ tertentu (antara 2,0-5,0) di dalam labu ukur $50 \mathrm{~mL}$. Sebagian kecil (sekitar $1 \mathrm{~mL}$ ) sampel larutan model diambil untuk analisis HPLC.

\subsection{Cara ekstraksi cair-cair}

Dari labu ukur, larutan dipipet sebanyak masingmasing $10 \mathrm{~mL}$ ke dalam empat corong pisah. Ke dalam masing-masing corong ditambahkan pelarut tertentu (nbutil asetat, iso butil asetat, metil isobutil keton, dan iso amil asetat) sebelum kemudian dikocok selama satu menit. Selanjutnya, larutan didiamkan hingga terbentuk dua fase, yaitu fase aquatik dan organik. Setelah kedua fase terpisah, dengan fase aquatik di bagian bawah, diambil $1 \mathrm{~mL}$ aliquot untuk dianalisis dan sisanya diukur $\mathrm{pH}$ nya menggunakan $\mathrm{pH}$ meter. Ekstraksi dilakukan pada tekanan ruang dan temperatur $4^{\circ} \mathrm{C}$.

\subsection{Analisis konsentrasi}

Alat yang digunakan adalah HPLC merek Biotronik tipe BT8300 yang bekerja dengan reversed phase. Kolom dari alat ini adalah bondapak C-18 dengan panjang $300 \mathrm{~mm}$. Alat ini beroperasi pada temperatur ruang dan tekanan $87 \mathrm{~kg} / \mathrm{cm}^{2}$. Sampel yang dianalisis dengan HPLC meliputi larutan model sebelum dan sesudah ekstraksi. Sampel sebelumnya perlu diencerkan dengan dapar fosfat $\mathrm{pH}$ 7,0 sebelum sampel sebanyak 10 $\mu \mathrm{L}$ disuntikan ke HPLC. Larutan model sebelum ekstraksi diencerkan 40-60 kali, sedangkan larutan sesudah ekstraksi diencerkan 10-30 kali untuk mendapatkan puncak kromatogram yang baik. Panjang gelombang yang digunakan pada HPLC adalah $220 \mathrm{~nm}$ dengan detektor UV. Fase gerak adalah metanol dengan dapar fosfat $\mathrm{pH} 7,0$ dan konsentrasi $0,02 \mathrm{~N}$, dengan perbandingan metanol: dapar 75:25 dimana penisilin $\mathrm{G}$ masih terdeteksi dengan baik dan derajat pemisahan puncak 6-APA dan PAA cukup besar. Laju alir fase gerak adalah konstan $1 \mathrm{~mL} /$ menit dan waktu retensi hasil pengamatan disajikan dalam tabel 1 .

Berdasarkan data yang diperoleh dari HPLC, maka dapat ditentukan persen perolehan untuk masing-masing senyawa yang dianalisis. Konsentrasi zat $\left(C_{i}\right)$ dihitung dengan persamaan berikut:

$C_{i}=m \times A$

\subsection{Penentuan persen perolehan}

Dalam percobaan ini, itentukan \% perolehan zat di fasa organik (Y) yang dirumuskan sebagai:

$Y=100-\left(\left(C o / C_{E}\right) \times 100\right)$ 
Tabel 1. Waktu retensi tiga komponen utama yang dipisahkan

\begin{tabular}{cc}
\hline Senyawa & Waktu retensi (menit) \\
\hline 6-APA & 0,105 \\
PAA & 0,110 \\
Penisilin G & 0,049 \\
\hline
\end{tabular}

2.6. Penentuan koefisien distribusi

Koefisien distribusi (D) dihitung dengan persamaan:

$\mathrm{D}=\left(C_{o}-C_{R}\right) / C_{R}$

\subsection{Penentuan koefisien partisi penisilin $\mathrm{G}$}

Dalam ekstraksi cair-cair secara batch, perbandingan konsentrasi penisilin di kedua fasa cenderung berharga tetap dan dinyatakan sebagai koefisien partisi $\left(K_{d}\right)$ berikut ini:

$K_{d}=H P_{o r g} / H P_{a q}$

Dari kriteria kesetimbangan termodinamika, lebih lanjut, eksktraksi jenis ini dapat dianggap hanya terjadi satu tahap kesetimbangan, sehingga persamaan 4 bila dinyatakan dalam bentuk perbandingan aktifitas adalah:

$K_{d}=a_{o r g} / a_{a q}$

Karena penisilin merupakan asam organik lemah (dituliskan sebagai HP), maka di dalam fase akuatiknya akan terjadi disosiasi membentuk ion $\left[H^{+}\right],\left[P^{-}\right]$, dan $[H P]$ sehingga bentuk koefisien distribusi penisilin dapat dinyatakan dalam:

$D=[H P]_{\text {org }} /\left([H P]_{a q}+[P-]_{a q}\right)$

Lebih lanjut, penisilin akan memiliki tetapan keasaman reaksi disosiasi $(\mathrm{Ka})$ :

$K_{a}=\left[H^{+}\right]\left[P^{-}\right] /[H P]$

Dengan mensubstitusikan nilai $\left[P^{-}\right]_{a q}$ dari persamaan 7 ke persamaan 6 , akan didapatkan:

$D=[H P]_{\text {org }} /\left\{[H P]_{a q}+\left([H P]_{a q} \times 10^{(p H-p K a)}\right)\right\}$

Dalam fungsi $K_{d}$ maka persamaan 8 dapat dinyatakan dalam:

$D=K_{d} /\left(1+10^{(p H-p K a)}\right)$

Untuk mengolah data hasil percobaan pada berbagai $\mathrm{pH}$ untuk masing-masing pelarut, maka $\mathrm{pKa}$ penisilin dioptimasi dengan menghitung selisih kuadrat terkecil antara koefisien distribusi hasil perhitungan (persamaan 9) dengan data percobaan menggunakan metode simpleks. Dari pKa hasil optimasi, koefisien partisi ditetapkan kembali dari persamaan yang sama. Diasumsikan bahwa harga $\mathrm{pKa}$ penisilin semula adalah 2,75 (Reschke dan Schügerl, 1984).

\subsection{Variasi percobaan}

Variasi percobaan ekstraksi dilakukan pada rentang $\mathrm{pH}$ 2,0-5,0, sedangkan pelarut organik yang digunakan yaitu n-butil asetat (NBA), iso butil asetat (IBA), metil isobutil keton (MIBK), dan iso amil asetat (IAA). Konsentrasi awal dari larutan model adalah penisilin $\mathrm{G}$ $1,782 \mathrm{mg} / \mathrm{mL}$, 6-APA $1,728 \mathrm{mg} / \mathrm{mL}$, dan PAA 1,088 $\mathrm{mg} / \mathrm{mL}$.

\section{Hasil dan Pembahasan}

Pada rentang $\mathrm{pH}$ 2,0-3,0, perolehan 6-APA dalam pelarut NBA meningkat dari $5,4 \%$ ke $38,2 \%$ seiring peningkatan $\mathrm{pH}$ ekstraksi. Selanjutnya, pada rentang $\mathrm{pH}$ 3,0-5,0, kenaikan $\mathrm{pH}$ menyebabkan turunnya perolehan 6-APA dari 38,2 \% ke 26,2\% (Gambar 1a). Hal tersebut terkait dengan harga $\mathrm{pKa}$ 6-APA yang merupakan senyawa amfoter, dengan pola disosiasi ditunjukkan pada Gambar 2. Di bawah pKa1 yang bernilai 2,3, maka 6APA dalam bentuk asam akan lebih dominan (membentuk spesi $\mathrm{COOH}$ ), sedangkan di atas $\mathrm{pKa}_{2}$ 4,9, maka akan terbentuk spesi $\mathrm{NH}_{3}{ }^{+}$yang merupakan anion. Kedua spesi tersebut cenderung lebih mudah larut dalam air (fasa akuatik) (Korzybski dkk., 1967). Di sisi lain, di antara kedua nilai pKa tersebut, akan terbentuk zwitter ion yang menyebabkan total muatan 6-APA menjadi netral dan lebih banyak terkestrak ke fase organik (tidak mudah larut dalam fasa akuatik).

Ekstraksi dengan menggunakan pelarut IBA, MIBK, dan IAA menunjukkan kecenderungan yang serupa dengan NBA, dengan peningkatan perolehan pada rentang 2,0-3,0 secara berturut-turut adalah 6,35\%$30,21 \%$, 5,07\%-15,70\%, dan 6,66\%-24,43\% (grafik ditampilkan pada Gambar 1.b-1.d). Dari semua pelarut yang diuji, perolehan 6-APA pada fase organik terendah diketahui adalah pada operasi ekstraksi batch di $\mathrm{pH}$ 2,0 dengan pelarut MIBK (sebesar 5,07\%).

Terkait dengan persen perolehan penisilin $G$ dan PAA, hasil percobaan untuk pelarut NBA ditunjukkan pada Gambar 1a. Dapat dilihat bahwa perolehan penisilin $\mathrm{G}$ cenderung menurun dengan peningkatan $\mathrm{pH}$. Untuk pelarut NBA, perolehan penisilin $\mathrm{G}$ berada pada rentang $37,31 \%-99,10 \%$, dengan nilai tertinggi pada $\mathrm{pH} 2,0$. Penyebabnya, pada $\mathrm{pH}$ 2,0, lebih banyak penisilin $\mathrm{G}$ yang tidak terdisosiasi (bersifat netral) karena $\mathrm{pKa}$ penisilin $G$ adalah bernilai 2,75 (Ponsford, 2000). Penisilin $\mathrm{G}$ yang netral memiliki kepolaran lebih rendah dibandingkan penisilin $\mathrm{G}$ yang bermuatan. Terlebih lagi, penisilin $\mathrm{G}$ dalam kondisi ini lebih mudah terlarut dalam pelarut organik non-polar. Di sisi lain, pada $\mathrm{pH} 3,0-5,0$ atau di atas harga pKa-nya, kondisi dominan dari penisilin $G$ adalah dalam bentuk anionnya, sehingga lebih polar dibandingkan kondisi netral dan sebagai hasilnya penisilin $\mathrm{G}$ lebih sulit terekstrak ke fase organik. Ekstraksi dengan pelarut lain memberikan kelakuan yang serupa, dengan perolehan tertinggi pada rentang $\mathrm{pH} 2,0-$ 3,0 . Untuk pelarut IBA, perolehan penisilin antara $60 \%$ 99\%, untuk MBK 84\%-99\%, dan untuk IAA 46\%-99\% (Gambar 1 (b)-(d)). 


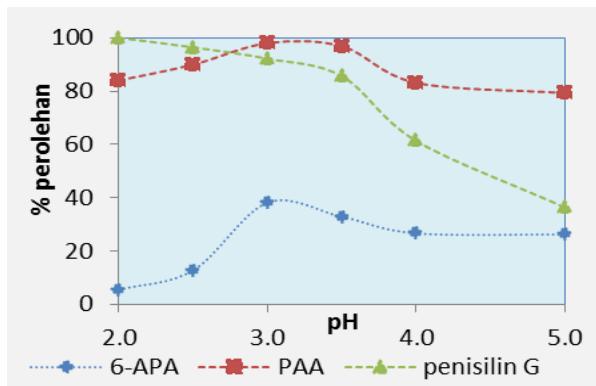

(a)

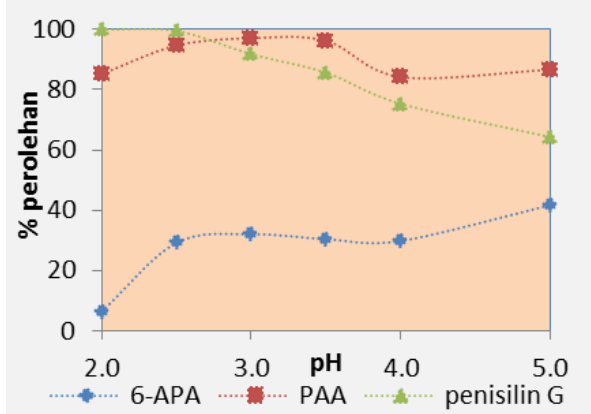

(b)

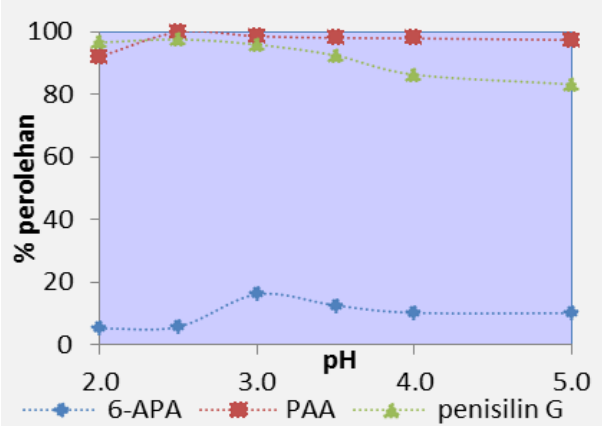

(c)

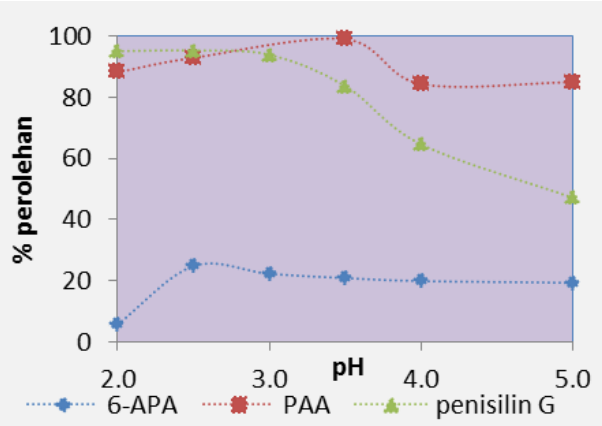

(d)

Gambar 1. Pengaruh $\mathrm{pH}$ terhadap perolehan 6-APA untuk pelarut (a) NBA, (b) IBA, (c) MIBK, dan (d) IAA

Secara umum, senyawa PAA seluruhnya menunjukkan perolehan pada rentang $85-100 \%$ untuk semua variasi pelarut dan dari $\mathrm{pH} \mathrm{2,0}$ hingga 5,0. Pola menurun dari komponen PAA hanya terjadi setelah $\mathrm{pH}$ 4,0. Hal ini dikarenakan PAA memiliki harga pKa yang lebih tinggi dari penisilin G, yaitu senilai 4,3 (Korzybski dkk., 1967; Othmer, 2000). Di bawah nilai tersebut, maka PAA yang berada dalam bentuk netral (non-polar) akan mendominasi. Kondisi ini menyebabkan PAA lebih mudah diekstrak dengan pelarut organik ketimbang senyawa 6-APA dan penisilin G.
Maka dari itu, dari pengamatan pengaruh $\mathrm{pH}$ terhadap kemudahan pemisahan 6-APA, relevansi yang dapat diambil adalah bahwa 6-APA mudah terekstrak ke pelarut organik bila berada di antara $\mathrm{pH}$ 2,3-4,9, sedangkan penisilin $\mathrm{G}$ dan PAA secara berturut-turut perlu berada di bawah pH 2,75 dan 4,3. Alhasil, pada operasi ekstraksi di pada rentang $\mathrm{pH}$ 2,0 dan $\mathrm{pH}$ 2,5 seperti dilakukan percobaan ini, pemisahan 6-APA bersifat paling efisien. Pemisahan di bawah $\mathrm{pH}$ 2,0 tentunya tidak disarankan karena perlu dilakukan pada kondisi yang sangat korosif dan dapat juga merusak keaktifan senyawa 6-APA (Dennen, 1967; Su dkk., 2016).

Berdasarkan Gambar 3, perolehan 6-APA terendah secara umum diperoleh untuk pelarut MIBK (di bawah $20 \%$ untuk rentang $\mathrm{pH} 2,0$ hingga 5,0. Hal ini menunjukkan bahwa MIBK merupakan pelarut yang paling efisien yang dapat digunakan untuk memisahkan 6-APA dari campurannya. Di lain pihak, perolehan penisilin $G$ dan PAA cenderung tinggi untuk pelarut NBA, iBA, MIBK, dan IAA (rata-rata di atas $90 \%$ pada rentang $\mathrm{pH}$ 2,0-3,0). Pelarut MIBK memberikan perolehan penisilin $G$ (dan PAA) tertinggi karena memiliki koefisien partisi (perbandingan jumlah penisilin G (atau PAA) di fase organik terhadap penisilin G (atau PAA) di fase akuatik) paling besar jika dibandingkan dengan pelarut lainnya. Perbandingan data koefisien untuk komponen penisilin $\mathrm{G}$ murni ( $K_{d}$ awal) dengan saat berada dalam campurannya dengan PAA dan 6-APA ( $K_{d}$ campuran) ditunjukkan pada Tabel 2.

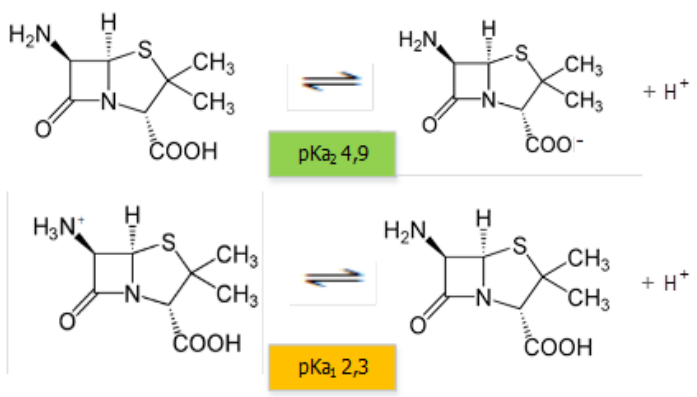

(a)

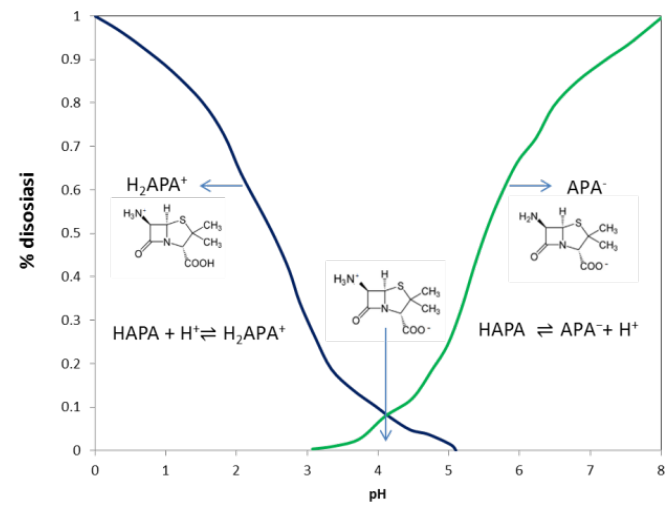

(b)

Gambar 2. (a) Reaksi disosiasi 6-APA, (b) Kurva \% disosiasi terhadap $\mathrm{pH}$ untuk senyawa 6-APA (diadaptasi dari (Korzybski dkk., 1967)) 


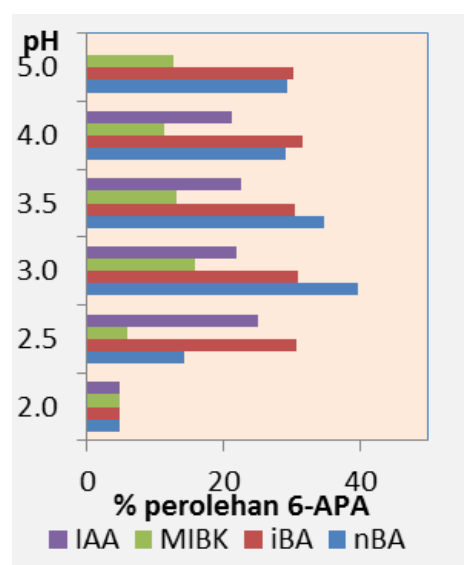

(a)

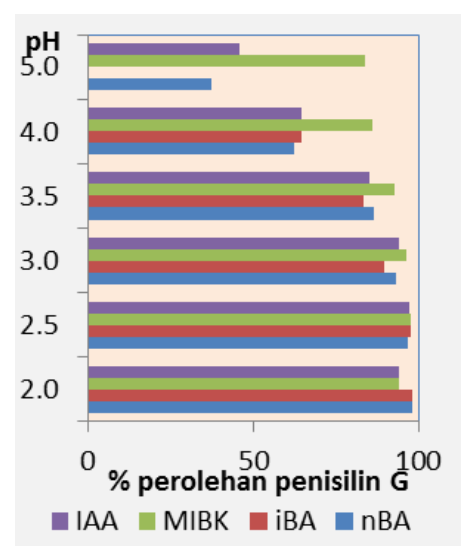

(b)

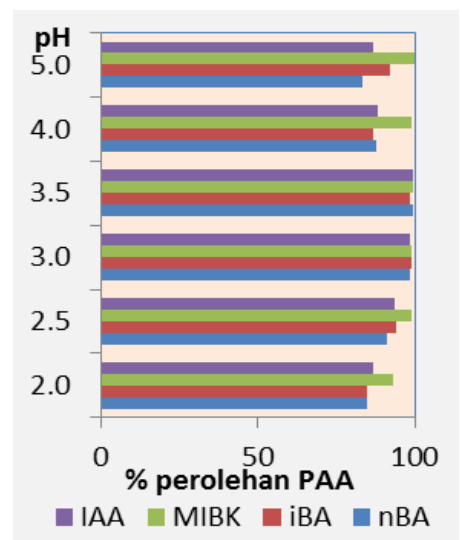

(c)

Gambar 3. Pengaruh jenis pelarut terhadap perolehan (a) 6-APA, (b), penisilin G, dan (c) PAA pada berbagai $\mathrm{pH}$ operasi

Tabel 2. Koefisien partisi $\left(K_{d}\right)$ penisilin $\mathrm{G}$

\begin{tabular}{ccc}
\hline Pelarut & $K_{d}$ & $K_{d}$ \\
awal & campuran \\
\hline n-butil asetat (NBA) & 21,47 & 10,91 \\
i-butil asetat (iBA) & 13,62 & 11,17 \\
i-amil asetat (IAA) & 12,05 & 10,53 \\
metil i-butil keton (MIBK) & 8,017 & 12,98 \\
\hline
\end{tabular}

Nilai $K_{d}$ tersebut diperoleh dari hasil optimasi pKa penisilin $G$ murni (estimasi awal 2,75) yang bernilai 3,015. Dari data tersebut, sangat jelas terjadi penurunan $K_{d}$ untuk kesemua pelarut, kecuali untuk MIBK. Hal ini kemungkinan disebabkan oleh pengaruh 6-APA yang dapat meningkatkan kelarutan penisilin $G$ pada pelarut yang memiliki kepolaran relatif lebih rendah dari MIBK. Sebagai perbandingan untuk kepolaran relatif, direpresentasikan data persentase kelarutan senyawa terkait dalam air, yaitu IBA 0,67\%, NBA 1,37\%, IAA 1,4\%, dan MIBK 1,7\% (Mann dan Marsden, 1963). Sebagai tambahan, dugaan tersebut mendukung hasil penelitian yang menunjukkan bahwa MIBK adalah pelarut yang paling cocok untuk memisahkan 6-APA dari PAA dan penisilin G. Perlu diketahui bahwa nilai $K_{d}$ dapat ditingkatkan dengan peningkatan temperatur dan penurunan $\mathrm{pH}$ karena kelarutan penisilin $\mathrm{G}$ akan semakin rendah dengan pengondisian tersebut (Zhu dkk., 1990). Maka dari itu, percobaan ini diselenggarakan pada temperatur $4^{\circ} \mathrm{C}$ agar memperoleh $K_{d}$ penisilin $\mathrm{G}$ dalam campuran yang setinggi-tingginya.

\section{Kesimpulan}

Dari percobaan yang telah dilakukan, hasil terbaik pemisahan 6-APA dari campuran penisilin G, 6-APA, dan PAA diperoleh pada rentang 2,0-3,0. Pelarut terbaik untuk pemisahan 6-APA di antara berbagai jenis pelarut adalah metil isobutil keton, dengan persentase perolehan mencapai 98\% untuk penisilin G, 5\% untuk 6-APA, dan $99 \%$ untuk PAA.

\section{Daftar Notasi}

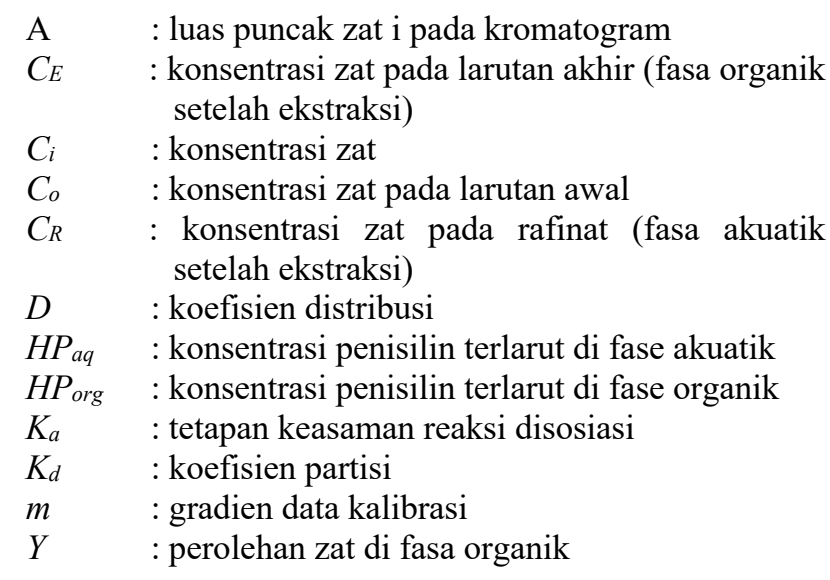

\section{Daftar Pustaka}

Batchelor, F.R.; Chain, E.B.; Hardy, T.L.; Mansford, K.R.L.; Rolinson, G.N., 6-Aminopenicillanic Acid III. Isolation and Purification. Proceedings of the Royal Society of London. Series B. Biological Sciences, 1961, 154(957), 498-508.

Bruggink, A.; Roos, E.C.; de Vroom, E., Penicillin Acylase in the Industrial Production of $\beta$-Lactam Antibiotics. Organic Process Research \& Development, 1998, 2(2), 128-133. 
Dennen, D.W., Degradation Kinetics of 6aminopenicillanic Acid. Journal of Pharmaceutical Sciences, 1967, 56(10), 1273-1276.

Elder, A.L., The History of Penicillin Production. Chemical Engineering Progress Sympsium Series, 1970, 66(100), 39-41.

Harvey, W.; Blanch, S.D.; Daniel, I.; C., W., Book Review: Comprehensive Biotechnology. The Principles, Applications and Regulations of Biotechnology in Industry, Agriculture and Medicine. Editor-in-Chief: M. Moo-Young. Angewandte Chemie International Edition, 1987, 26(6), 588.

Huper, F., Production of 6-Aminopenicillanic Acid. US Patent 3,900,488 A, 1972.

Ivaskhiv, E., Chemical Method for Determination of 6APA in Fermentation Broths. Journal of Pharmaceutical Sciences, 1964, 36, 2506-2507.

Korzybski, T.; Kowszyk-Gindifer, Z.; Kuryłowicz, W., Antibiotics. Volume II: Origin, Nature and Properties, Paryski, E., ed.. Oxford: Pergamon Press, 1967.

Mann, C.; Marsden, S., Solvent Guide. Kensington: Cleaver-Hume Press Ltd., 1963.

Misek, T., Recommended Systems for Liquid Extraction Studies. London: The Institution of Chemical Engineers, 1978.

Ponsford, R.J., Penicillins and Others, $\beta$-Lactams, KirkOthmer Encyclopedia of Chemical Technology. Hoboken: John Wiley \& Sons, Inc., 2000, pp. 1-26.
Reschke, M.; Schügerl, K., Reactive Extraction of Penicillin I: Stability of Penicillin G in The Presence of Carriers and Relationships for Distribution Coefficients and Degrees. The Chemical Engineering Journal, 1984, 28(1), B1-B9.

Schugerl, K.; Degener, W., Recovery of Low-MolecularWeight Compounds from Complex Aqueous Mixtures by Extraction. International Chemical Engineering, 1992, 32, 29-39.

Singh, V.; Goyal, S.G., Penicillin G Acylase, a Biocatalyst and Its Potential Application. International Journal of Scientific \& Engineering Research, 2014, 5(5), 153-158.

Su, M.; Sun, H.; Zhao, Y.; Lu, A.; Cao, X.; Wang, J., Degradation Kinetics and Mechanism of a $\beta$-Lactam Antibiotic Intermediate, 6-Aminopenicillanic Acid, in a New Integrated Production Process. Journal of Pharmaceutical Sciences, 2016, 105(1), 139-146.

Vandamme, E.J.; Voets, J.P., Microbial Penicillin Acylases. Advances in Applied Microbiology, 1974, 17, 311-369.

Zhu, Y.; Evans, L.B.; Chen, C.-C., Representation of Phase Equilibrium Behavior of Antibiotics. Biotechnology Progress, 1990, 6(4), 266-272.

Zhukovskaya, S.A., Nomogram for Calculation of Countercurrent Extraction of Penicillin. Zhurnal Prikladnoi Khimii, 1974, 47, 559-563. 